\title{
SISTEM IDENTIFIKASI CITRA JANIN TERHADAP ASUPAN GIZI IBU HAMIL DENGAN MENGGUNAKAN METODE SOBEL DAN KIRSCH
}

\author{
Evrita Lusiana Utari \\ Fakultas Sains \& Teknologi, Program Studi Teknik Elektro \\ Universitas Respati Yogyakarta \\ Email: evrita_lusiana@yahoo.com \\ Rr. Dewi Ngaisyah \\ Fakultas Ilmu Kesehatan, Program Studi Gizi \\ Universitas Respati Yogyakarta \\ Email: dewi.fikes@yahoo.co.id \\ Herison Surbakti \\ Fakultas Sains \& Teknologi, Program Studi Sistem Informasi \\ Universitas Respati Yogyakarta \\ Email: herisonsurbakticc@gmail.com
}

\begin{abstract}
ABSTRAK
Sistem Identifikasi digunakan untuk mendeteksi perubahan citra pada janin sehingga terbentuk tepi-tepi suatu obyek citra yang dimanfaatkan untuk mendeteksi citra janin. Metode citra yang digunakan dengan membandingkan antara metode Sobel dan metode Kirsch. Metode identifikasi ini digunakan untuk mendapatkan perbedaan intensitas. Pada pemeriksaan ibu hamil, kita sering melihat janin dengan berbagai bentuk, ukuran anatomis gerakan serta hubungan dengan jaringan. Seiring dengan kemajuan informasi dan teknologi, maka memungkinkan untuk mengembangkan aplikasi yang dapat membantu manusia untuk mengenali bentuk-bentuk janin terhadap asupan gizi ibu hamil.

Pengolahan citra digital adalah bidang yang berkembang dari teknologi digital dengan aplikasi deteksi janin dalam sains dan teknik. Salah satu bentuk janin yang terkait dengan pengolahan citra adalah pengenalan pola. Identifikasi janin dimulai dengan akuisisi data citra, pengolahan citra, deteksi tepi citra, dengan menggunakan metode Sobel dan metode Kirsch. Tujuan dari identifikasi ini untuk melihat kaitan antara asupan gizi ibu hamil dengan janin yang dikandungnya dengan melihat hasil citra yang diambil dari USG. Pengenalan pola akan mendeteksi citra janin sebagai masukan data. Hasil dari pengenalan pola tersebut akan dibandingkan dengan data citra yang lainnya. Berdasarkan hasil pengujian data citra janin metode Kirsch memiliki kinerja lebih baik dibandingkan metode Sobel. Hal ini dapat dilihat dari jumlah piksel penyusun tepi obyek memiliki nilai lebih besar dibandingkan dengan metode Sobel. Dan untuk tingkat akurasinya metode Kirsch memiliki tingkat akurasi lebih tinggi dan metode Sobel.
\end{abstract}

Kata kunci: USG, identifikasi, janin

\begin{abstract}
The identification system is used to detect image changes in the fetus so that the edges of an image object are formed which are used to detect fetal images. The image method used is by comparing the Sobel method and the Kirsch method. This identification method is used to get the difference in intensity. In the examination of pregnant women, we often see fetuses of various shapes, sizes, anatomical movements and relationships with tissues. Along with advances in
\end{abstract}


information and technology, it is possible to develop applications that can help humans to recognize fetal forms on the nutritional intake of pregnant women.

Digital image processing is a growing field of digital technology with fetal detection applications in science and engineering. One form of the fetus associated with image processing is pattern recognition. Fetal identification begins with image data acquisition, image processing, image edge detection, using the Sobel method and the Kirsch method. The purpose of this identification is to see the relationship between the nutritional intake of pregnant women and the fetus they are carrying by looking at the results of images taken from ultrasound. Pattern recognition will detect an image of the fetus as data input. The results of the pattern recognition will be compared with other image data. Based on the results of testing fetal image data, the Kirsch method has better performance than the Sobel method. This can be seen from the number of pixels that compose the edges of the object which has a greater value than the Sobel method. And for the level of accuracy the Kirsch method has a higher level of accuracy and the Sobel method

Keywords: ultrasound, identification, fetus

\section{PENDAHULUAN}

Dalam pemeriksaan rutin ibu hamil hal sering dilakukan dokter untuk mengetahui keadaan dari janin dengan melakukan pengambilan citra janin. Citra janin diperoleh dari hasil pencintraan alat Ultrasonografi (USG). Ultrasonografi (USG) merupakan salah satu pencitraan diagnostik untuk pemeriksaan organ dalam tubuh. imaging diagnostic yang digunakan untuk pemeriksaan keadaan alat-alat vital dalam tubuh manusia, dengan USG dapat dipelajari bentuk, ukuran anatomis, gerakan serta hubungan dengan jaringan di sekitarnya [4]. Pada umumnya pemeriksaan dengan USG bersifat non-invansif, tidak menimbulkan rasa sakit pada penderita, dapat dilakukan dengan cepat dan cukup aman jika dilakukan dengan standarisasi yang ada [9].

Penggunaan USG dalam dunia kesehatan dikenal juga dengan istilah sonografi obsetri, dilakukan pada kehamilan yang bertujuan untuk mengetahui anatomi janin. Pemeriksaan anatomi janin merupakan bagian dari standar pemeriksaan ultrasonografi obsetri yang dilakukan untuk mengidentifikasi organ internal utama janin. Pemeriksaan ini terbagi menjadi beberapa bagian yang disebut dengan trimester. Pada trimester I, pemeriksaan anatomi janin sangat terbatas, dikarenakan ukuran embrio dan janin masih kecil. Pada akhir trimester I dapat dikenali kepala, badan, tonjolan ekstremitas dan denyut jantung [4]. Salah satu hasil pemeriksaan sonografi obsetri yang didapatkan pada trimester II dan III adalah kepala. Kepala pada janin umumnya kepala berbentuk oval, bulat (brachcephaly) dan elips (dolichocephaly), serta memiliki ukuran yang berbeda-beda sesuai dengan umur atau gestasi janin itu sendiri. Untuk menemukan ukuran kepala pada janin dilakukan proses perekaman oleh transduser yang dilakukan oleh dokter atau ahli medis, hasil dari perekaman kepala yang baik jika kepala terdeteksi mendekati bentuk seperti bola rugby atau elips, dengan bentuk lebih bundar pada daerah posterior dan lebih lancip pada daerah anterior [9].

Aplikasi deteksi janin merupakan salah satu cara mengetahui bentuk janin yang terkait dengan menggunakan pengolahan citra. Menurut [5] pengolahan citra janin dengan menggunakan membandingkan antara metode prewitt, dan canny terlihat tingkat akurasinya mencapai $85 \%$.

Peran asupan zat gizi makronutrien ibu hamil terhadap berat badan lahir bayi (Syari, 2015). Dalam pertumbuhan dan perkembangan anak ditentukan oleh kondisi janin saat didalam kandungan dan asupan zat gizi makanan ibu selama kehamilan. Ibu dengan asupan makanan kurang saat hamil akan mengalami gangguan pertumbuhan dan Berat Badan Lahir Rendah 
(BBLR). Tujuan penelitian ini adalah untuk mengetahui peran asupan zat gizi makronutrien ibu hamil terhadap berat badan lahir bayi. Penelitian ini merupakan studi analitik observasional dengan rancangan case control. Subjek kasus yaitu 19 orang ibu bersalin aterm dengan bayi BBLR, dan subjek kontrol 21 orang ibu bersalin dengan bayi berat badan lahir normal di RSUD Rasidin dan RST Reksodiwiryo Kota Padang yang memenuhi kriteria inklusi, dengan teknik consecutive sampling. Analisis menggunakan uji chi square dengan derajat kepercayaan $95 \%(\alpha=$ $0,05)$.

\section{TINJAUAN PUSTAKA}

Penggunaan USG dalam dunia kesehatan dikenal juga dengan istilah sonografi obsetri, dilakukan pada kehamilan yang bertujuan untuk mengetahui anatomi janin. Pemeriksaan anatomi janin merupakan bagian dari standar pemeriksaan ultrasonografi obsetri yang dilakukan untuk mengidentifikasi organ internal utama janin. Pemeriksaan ini terbagi menjadi beberapa bagian yang disebut dengan trimester. Pada trimester I, pemeriksaan anatomi janin sangat terbatas, dikarenakan ukuran embrio dan janin masih kecil. Pada akhir trimester I dapat dikenali kepala, badan, tonjolan ekstremitas dan denyut jantung [4]. Tepi atau sisi dari sebuah obyek adalah daerah di mana terdapat perubahan intensitas warna yang cukup tinggi. Proses deteksi tepi (edge detection) akan melakukan konversi terhadap daerah ini menjadi dua macam nilai yaitu intensitas warna rendah atau tinggi, contoh bernilai nol atau satu. Deteksi tepi akan menghasilkan nilai tinggi apabila ditemukan tepi dan nilai rendah jika sebaliknya. Pelacakan tepi merupakan operasi untuk menemukan perubahan intensitas lokal yang berbeda dalam sebuah citra [6] [11]. Gradien adalah hasil pengukuran perubahan dalam sebuah fungsi intensitas, dan sebuah citra dapat dipandang sebagai kumpulan beberapa fungsi intensitas kontinyu sebuah citra. Perubahan mendadak pada nilai intensitas dalam suatu citra dapat dilacak menggunakan perkiraan diskrit pada gradien. Gradien disini adalah kesamaan dua dimensi dari turunan pertama dan didefinisikan sebagai vektor [6]. Metode deteksi tepi yang digunakan pada penelitian ini yaitu metode atau operator Kirsch, Robinson, Sobel dan Prewitt.

Menurut EL Utari [5] Aplikasi yang teknologi informasi dapat membantu manusia untuk mengenali bentuk-bentuk janin Pengolahan citra digital adalah bidang yang berkembang dari teknologi digital dengan aplikasi deteksi janin dalam sains dan teknik. Salah satu bentuk janin yang terkait dengan pengolahan citra adalah pengenalan pola. Sistem identifikasi tepi janin dengan Canny dan Prewitt hanya mencapai $84 \%$.

Metode deteksi tepi merupakan salah satu operasi dalam pengolahan citra digital yang berguna untuk mengidentifikasi garis batas atau tepian pada obyek. Ada banyak metode dalam deteksi tepi, namun penelitian ini mengunakan metode Sobel dikarenakan metode Sobel mempunyai kelebihan untuk mengurangi derau dari metode deteksi tepi lainnya. Dalam penelitian ini digunakan 3 sampel citra patah tulang yang berbeda-beda, dimana citra awal terlebih dahulu dilakukan perbaikan citra berbasiskan transformasi Fourier untuk mengurangi derau pada citra. Hasil pengujian dari skripsi ini menunjukkan bahwa hasil deteksi tepi pada citra patah tulang lebih baik jika citra aslinya dilakukan proses perbaikan citra terlebih dahulu sebelum dilakukan proses deteksi tepi Sobel, meskipun metode Sobel mempunyai kelebihan untuk mengurangi noise dari metode deteksi tepi lainnya [10].

\subsection{Landasan Teori}

Pertama kali Ultrasonografi (USG) digunakan dalam bidang teknik untuk radar, yaitu SONAR (Sound, Navigation, and Ranging) oleh Langevin (1918), seorang perancis pada waktu perang dunia I, untuk mengetahui adanya kapal selam musuh. Kemudian digunakan dalam pelayaran untuk menentukan kedalaman laut. USG merupakan salah satu pencitraan diagnostik untuk pemeriksaan organ dalam tubuh manusia, untuk mempelajari bentuk, ukuran antomis, gerakan serta hubungan dengan jaringan sekitarnya. Pemeriksaan ini bersifat non-invasif yaitu 
tidak menimbulkan rasa sakit pada penderita, dapat dilakukan dengan cepat, aman dan data yang diperoleh mempunyai nilai diagnostik tinggi. Tak ada kontra indikasinya, karena pemeriksaan ini sma sekali tidak akan memperburuk penyakit penderita [4].

\subsection{Fungsi Ultrasonografi}

Ultrasonografi adalah sebuah teknik diagnostik pencitraan menggunakan suara ultra yang digunakan untuk mencitrakan organ internal dan otot, struktur organ dan luka patologi, membuat teknik ini berguna untuk memeriksa organ dalam tubuh manusia. Dalam fisika, istilah "suara ultra" termasuk ke seluruh energi akustik dengan sebuah frekuensi di atas pendengaran manusia (20.000 Hertz), penggunaan umumnya dalam penggambaran medis melibatkan sekelompok frekuensi yang ratusan kali lebih tinggi. Diagnostik Ultrasonografi umumnya beroperasi pada frekuensi dari 1 sampai 10 Megahertz (MHz). Dalam kasus kehamilan, Ultrasonografi digunakan oleh dokter spesialis kandungan untuk memperkirakan usia kandungan dan memperkirakan hari persalinan. Dalam dunia kedokteran secara luas, alat ultrasonografi digunakan sebagai alat bantu untuk melakukan diagnosa atas bagian tubuh yang terbangun dari cairan. Bentuk penggunaan klinis ultrasonografi antara lain:

- Menemukan dan menentukan letak massa dalam rongga perut dan pelvis.

- Membedakan kista dengan massa yang solid.

- Mempelajari pergerakan organ (jantung, aorta, vena kafa), maupun pergerakan janin dan jantungnya.

- Pengukuran dan penentuan volume massa organ tubuh. Pengukuran aneurisma arterial, fetal sefalometri, menentukan kedalaman dan letak suatu massa untuk bioksi. Menentukan volume massa ataupun organ tubuh tertentu (misalnya buli-buli, ginjal, kandung empedu, ovarium, uterus, dan lain-lain).

- Bioksi jarum terpimpin. Arah dan gerakan jarum menuju sasaran dapat dimonitor pada layar USG.

- Menentukan perencanaan dalam suatu radioterapi. Berdasarkan besar tumor dan posisinya, dosis radioterapi dapat dihitung dengan cepat. Selain itu setelah radioterapi, besar dan posisi tumor dapat pula diikuti.

Mendiagnosis berbagai kelainan pada pembuluh darah seperti arteri karotis, penyumbatan dinding arteri (USG Doppler).

\subsection{Prinsip Kerja Ultrasonografi}

Dalam pemeriksaan USG menggunakan frekwensi 1- $10 \mathrm{MHz}$ (1- 10 juta Hz). Gelombang suara frekwensi tinggi tersebut dihasilkan dari kristal-kristal yang terdapat dalam suatu alat yang disebut transducer. Perubahan bentuk akibat gaya mekanis pada kristal, akan menimbulkan tegangan listrik. Fenomena ini disebut efek Piezo-electric, yang merupakan dasar perkembangan USG. Bentuk kristal juga akan berubah bila dipengaruhi oleh medan listrik. Sesuai dengan polaritas medan listrik yang melaluinya, kristal akan mengembang dan mengkerut, maka akan dihasilkan gelombang suara frekuensi tinggi. 


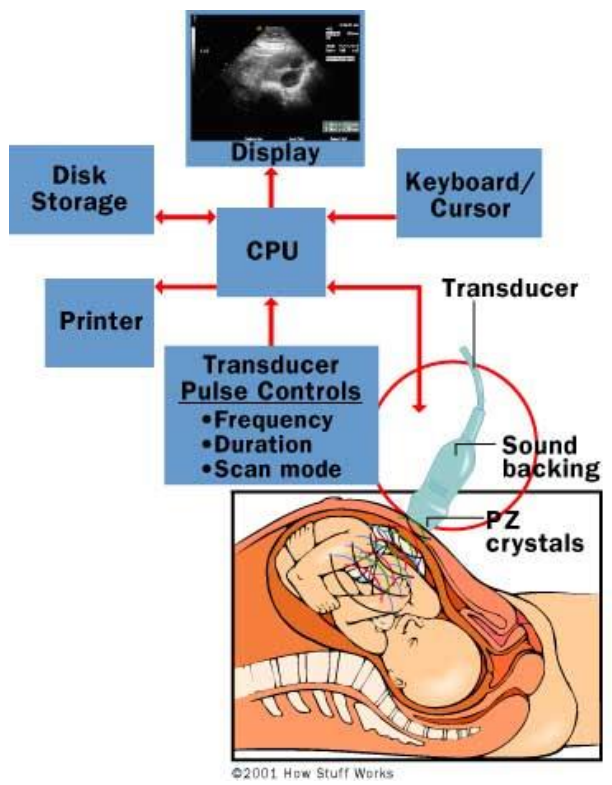

Gambar 1. Skema Prinsip Kerja Ultrasonografi

\subsection{Proses Pencitraan Ultrasonografi}

Tahapan awal pencitraan dimulai tahapan pembentukan gelombang ultrasound oleh rangkaian pulsa transmitter dengan cara mengirim tegangan listrik ke bagian transduser yang berfungsi pembentukan gelombang ultrasound. Komponen ini juga berpengaruh terhadap pengaturan laju transmisi pulsa yang disebut pulse repetition frequency (prf), amplitudo pulsa dan pulse repetition period (prp). Dapat dilihat pada Gambar 2.

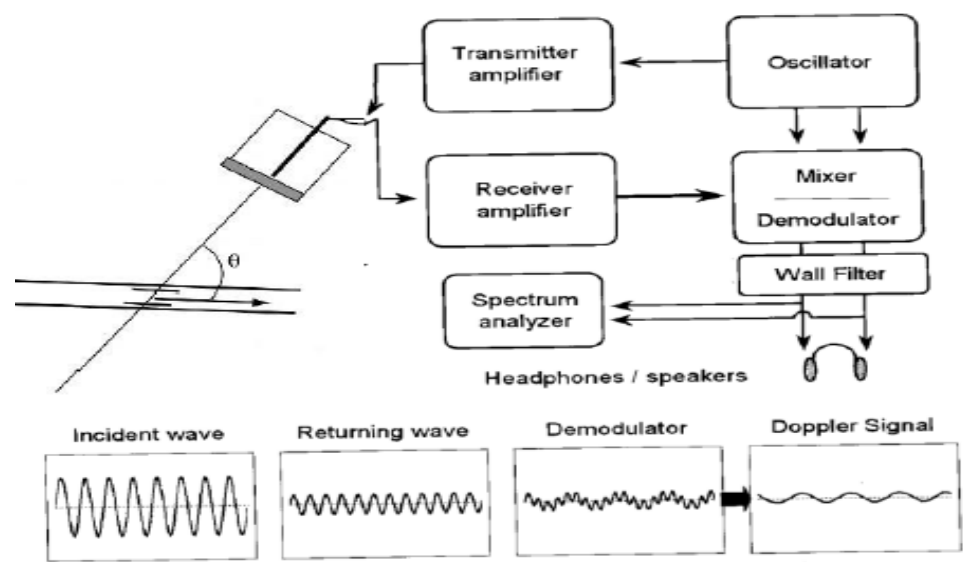

Gambar 2. Skema Desain Pencitraan Ultrasonografi

(Sumber: The Essential Physics of Medical Imaging, Bushberg, 2002)

Transduser tahapan berikutnya mengirim gelombang ultrasound ke tubuh pasien, sebagian gelombang ultrasound direfleksikan yang merupakan echo nantinya diolah menjadi gambar dan 
diterima receiver transduser. Signal echo yang dihasilkan diatur agar mempunyai magnitude yang sama baik di permukaan atau echo yang berasal dari dalam oleh bagian swept gain compensation.

\subsection{Citra}

Citra merupakan kamus Webster didefinisikan sebagai "Suatu representasi, kemiripan atau tiruan dari obyek atau sesuatu, suatu deskripsi grafik, atau sesuatu yang diperkenalkan untuk merepresentasikan sesuatu yang lain". Citra sesungguhnya merupakan gambaran isyarat dua dimensi. Dan untuk dapat diproses dengan menggunakan komputer, citra disajikan dalam bentuk digital. Citra digital memuat data numeris dalam dua dimensi (matriks) tentang keabuan (gray level) yang beragam nilainya pada tiap-tiap pixel (picture element).[1]

Ada beberapa tipe dasar citra (citra digital), yaitu:

- Citra indeks (citra berupa 1 matrik angka dan 1 matrik peta-warna (mx3))

- Citra intensitas (tiap pixel berisi informasi aras keabuan, antara 0 (genap) hingga 255 (paling putih)

- Citra biner (tiap pixel memuat data biner 0 dan 1 saja)

- Citra RGB (per pixel (24 bit) memuat info 3 warna: merah, hiaju, dan biru ( 8 bit)

Berkaitan dengan pengolahan citra digital terdapat berbagai tipe format berkas data suatu citra digital untuk dapat disimpan (sebagai arsip) dan ditransfer antar pengguna atau antar sistem. Beberapa contoh tipe format berkas adalah: tif, gif, bmp, pcx, jpg, dan png.

Citra digital yang akan diolah disesuaikan dengan keperluan atau tujuannya untuk perbaikan, restorasi, kompresi, persepsi, atau analisis citra. Masing-masing tujuan ini mempunyai permasalahan khas sehingga teknik penyelesaiannya pun beragam.

\subsection{Sistem Identifikasi}

Sistem Identifikasi adalah metode yang dapat untuk mengidentifikasi garis tepi, yaitu garis yang memisahkan antara objek dengan latar belakang (background). Sistem identifikasi menggunakan metode deteksi tepi merupakan pengolahan citra tingkat dasar yang diperlukan untuk melakukan pengolahan citra pada tingkat yang lebih tinggi. Sistem deteksi tepi banyak digunakan dalam analisa pengolahan citra untuk berbagai macam tujuan. Metode deteksi tepi ada beberapa macam, diantaranya menggunakan metode Sobel dan metode kirsch.

\subsection{Metode Sobel}

Metode Sobel merupakan algoritma deteksi tepi yang menggunakan Sobel Operator, yaitu sepasang kernel berupa matriks berukuran 3 × 3 untuk mendeteksi tepi vertikal dan horizontal.

\begin{tabular}{|c|c|c|}
\hline+1 & +2 & +1 \\
\hline 0 & 0 & 0 \\
\hline-1 & -2 & -1 \\
\hline \multicolumn{3}{|c|}{$\mathrm{Gx}$}
\end{tabular}

\begin{tabular}{|c|c|c|}
\hline-1 & 0 & +1 \\
\hline-2 & 0 & +2 \\
\hline-1 & 0 & +1 \\
\hline \multicolumn{3}{|c|}{ Gy }
\end{tabular}

\section{Gambar 3. Operator Sobel}

Kombinasi kedua kernel tersebut digunakan untuk menghitung jarak absolut sebuah gradient namun bisa juga diaplikasikan secara terpisah untuk menghitung masing-masing proses vertikal dan horizontal. Untuk menghitung jarak gradient, digunakan persamaan berikut:

$$
|\mathrm{G}|=\sqrt{\mathrm{Gx}^{2}+\mathrm{Gy}^{2}}
$$



berikut:

Kemudian untuk menghitung arah dari garis tepi yang dihasilkan, digunakan persamaan

$$
\theta=\arctan (\mathrm{Gx} / \mathrm{Gy})
$$

\subsection{Metode Kirsch}

Deteksi tepi operator Kirsch diperkenalkan oleh Kirsch pada tahun 1971. Operator ini identik dengan matriks $3 \times 3$ atau jendela ukuran $3 \times 3$ piksel, dengan $\mathrm{k} 0$ samapai $\mathrm{k} 7$ dihitung menggunakan kernel yang ditunjukkan pada Gambar 4.

\begin{tabular}{|c|c|c|}
\hline-3 & -3 & 5 \\
\hline-3 & 0 & 5 \\
\hline-3 & -3 & 5 \\
\hline
\end{tabular}

$\mathrm{k}_{0}$ Timur (east)

\begin{tabular}{|c|c|c|}
\hline 5 & 5 & -3 \\
\hline 5 & 0 & -3 \\
\hline-3 & -3 & -3 \\
\hline \multicolumn{4}{|c}{$k_{3}$ Barat Laut }
\end{tabular}

(north west)

\begin{tabular}{|c|c|c|}
\hline-3 & -3 & -3 \\
\hline-3 & 0 & -3 \\
\hline 5 & 5 & 5 \\
\hline
\end{tabular}

$\mathrm{k}_{6}$ Selatan

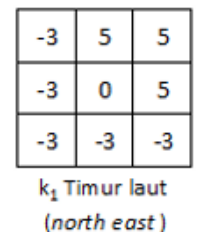

\begin{tabular}{|c|c|c|}
\hline 5 & -3 & -3 \\
\hline 5 & 0 & -3 \\
\hline 5 & -3 & -3 \\
\hline
\end{tabular}

$\mathrm{k}_{4}$ Barat (west)

\begin{tabular}{|c|c|c|}
\hline-3 & -3 & 3 \\
\hline-3 & 0 & 5 \\
\hline-3 & 5 & 5 \\
\hline \multicolumn{3}{|c|}{$k_{7}$ Tenggara } \\
(south east)
\end{tabular}
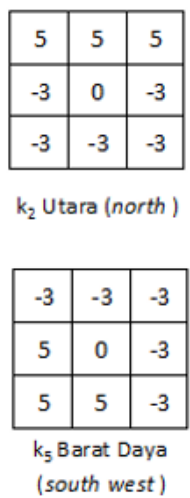

(south west)

Gambar 4. Operator Kirsch

\subsection{Pengaruh Gizi Terhadap Ibu Hamil}

Gizi memegang peranan penting dalam siklus hidup manusia. Masa kehamilan merupakan periode yang sangat menentukan kualitas sumber daya manusia dimasa depan. Karena tumbuh kembang anak ditentukan pada saat masa kehamilan atau masa janin di dalam kandungan. Kekurangan gizi pada ibu hamil dapat mengakibatkan bayi lahir dalam berat badan rendah (BBLR), prematur, sehingga dapat berdampak gizi terhadap bayi [13].

\section{ALUR PENELITIAN}

Dari Gambar 5 menjelaskan tentang alur penelitian 


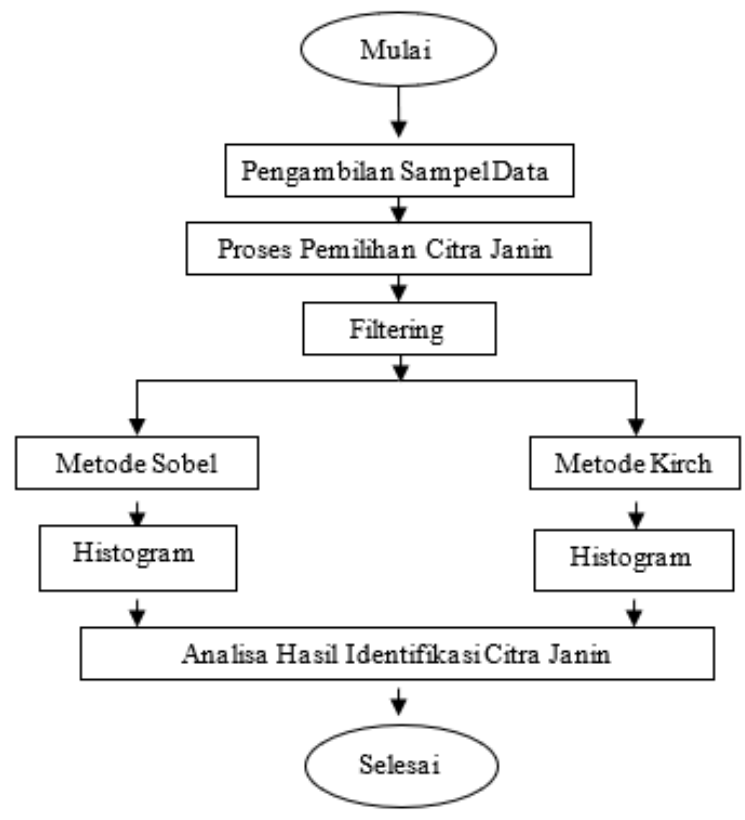

Gambar 5. Alur Penelitian

Penelitian ini dilaksanakan secara bertahap sebagaimana yang disajikan dalam Gambar 5 . Adapun tahapan-tahapan penelitian dapat dijelaskan sebagai berikut:

Tahap 1. Pengambilan data penelitian

Pengambilan sampel penelitian berupa citra janin dibantu oleh dokter spesialis kandungan yang berpengalaman. Untuk memastikan citra janin yang yang diambil untuk penelitian merupakan sampel yang tepat untuk digunakan dalam penelitian.

Tahap 2. Pemilihan hasil citra Janin

Pemilihan data citra janin bertujuan untuk mendapatkan hasil citra janin yang sesuai dengan kebutuhan.

Tahap 3. Sistem Identifikasi Citra Janin

Pengujian citra janin dengan menggunakan metode Kirsch dan Sobel.

Tahap 4. Analisis Hasil Deteksi Tepi

Untuk mendapatkan hasil penelitian yang dapat dipertanggungjawabkan, maka analisis hasil penelitian ini akan dilaksanakan secara bertahap, untuk mendapatkan hasil akurasi yang maksimal diantara 2 metode tersebut.

\subsection{Pra Pengolahan Citra}

Tahapan pra-pemrosesan meliputi pengolahan citra janin dengan menggunakan tapis melakukan pemfilteran oleh noise. Untuk mengatasi noise tersebut perlu dilakukan usaha untuk memperbaiki kualitas citra itu. Salah satunya adalah dengan filtering citra baik secara linear maupun secara non-linear. Mean filter merupakan salah satu filtering linear yang berfungsi untuk memperhalus dan menghilangkan noise pada suatu citra yang bekerja dengan menggantikan intensitas nilai pixel dengan rata-rata dari nilai pixel tersebut dengan nilai pixel-pixel tetangganya.[2] Pada preprocessing ini, dilakukan dua tahap, yaitu pemotongan dan penyamaan ukuran citra. Tahap ini dilakukan dengan tujuan memperoleh bagian citra sesuai kebutuhan penelitian ini. Proses pemotongan dan penyamaan ukuran citra dilakukan secara manual. Proses cropping dan resizing dilakukan dengan menggunakan software Adobe Photoshop CS3. Citra awal dari data rontgen toraks berukuran 2010x2010 pixel. Setelah dilakukan proses ini, citra menjadi 
berukuran 1760x1760 pixel. Pada penelitian ini, dilakukan perubahan dimensi citra menjadi lebih kecil dari citra awal, yaitu citra awal berdimensi 1760x1760 pixel menjadi berdimensi 320x320 pixel. Hasil dari tahapan ini kemudian semua citra disimpan secara berkelompok untuk setiap kelas dalam MATLAB file. Penyimpanan secara berkelompok tersebut diguanakan untuk tahapan selanjutnya.

\subsection{Pemilihan Data Hasil Citra Janin}

Data diperoleh dari beberapa rumah sakit diantaranya RS Hermina, RS JIH dan juga Data Onlien. Data citra awal meliputi usia kehamilan janin. Data yang diperoleh berdasarkan hasil citra digital yang diperoleh dari beberapa rumah sakit dimana mewakili kondisi janin dengan kondisi janin yang normal dan tidak normal. Kondisi dapat dilihat dari hasil pencitraan awal dan diagnosa awal dari dokter spesialis kandungan. dapat dilihat pada Tabel 1 berikut ini:

Tabel 1. Data Citra Janin

\begin{tabular}{|c|c|c|}
\hline No & Citra Janin & Usia Kehamilan \\
\hline Janin 1 & & $\begin{array}{c}\text { Trimester 2-3 } \\
\text { (dari RS JH) }\end{array}$ \\
\hline Janin 2 & & \\
\hline Janin 3 & & $\begin{array}{c}\text { 12 Week 6 day } \\
\text { (Trimester 2 data online) }\end{array}$ \\
\hline Janin 4 & & \\
\hline
\end{tabular}

\subsection{Proses Pengolahan Citra}

\subsubsection{Median Filter}

Metode ini dapat menghilangkan noise pada citra, yaitu bintik-bintik putih di sekitar paru. Sehingga gambar yang dihasilkan menjadi lebih jelas. Proses median filter beserta kernel dengan ukuran kernel sesuai toolbox Matlab. Proses median filter beserta kernel dengan ukuran kernel sesuai toolbox Matlab. Median filter adalah salah satu filtering non-linear yang mengurutkan nilai intensitas sekelompok pixel, kemudian mengganti nilai pixel yang diproses dengan nilai mediannya. Median filter telah digunakan secara luas untuk memperhalus dan mengembalikan bagian dari citra yang mengandung noise yang berbentuk bintik putih. Ditunjukkan pada Tabel 2. 
Tabel 2. Proses Filterisasi

\begin{tabular}{|c|c|c|}
\hline Nama Data & Data Asli & Hasil Median Filtering \\
\hline $\operatorname{Ianin} 1$ & & \\
\hline $\operatorname{Ianin} 2$ & & \\
\hline $\operatorname{Lanin} 3$ & & \\
\hline $\operatorname{Janin} 4$ & & \\
\hline
\end{tabular}

\subsection{Proses Deteksi dengan menggunakan Metode Kirch dan Sobel}

Proses Deteksi tepi berfungsi untuk mengidentifikasi garis batas (boundary) dari suatu objek yang terdapat pada citra. Proses ini digunakan untuk mengidentifikasi citra janin dengan metode Kirch. Penelitian ini dilakukan dengan tahapan-tahapan mulai penyiapan data citra janin, prapemrosesan hingga pasca pemrosesan [12]. Tahapan penyiapan data sampel citra janin dalam penelitian ini dengan cara melakukan pengambilan gambar hasil citra USG, kemudian melakukan seleksi kualitas dari hasil gambar. Tepi dari sebuah obyek adalah daerah dimana ada perubahan intensitas warna yang cukup tinggi. Deteksi Tepi merupakan pendekatan yang paling umum digunakan untuk mendeteksi diskontinuitas graylevel (nilai intensitas), seperti diskontinuitas yang dideteksi oleh penggunaan turunan pertama dan kedua. Metode Krisch menggunakan citra digital yang dengan dimensi 586x533 selanjutnya dilakukan konversi citra digital ke dalam bentuk matriks di mana ukuran matriks yang digunakan adalah ukuran 5x5. Proses identifikasi dengan metode Sobel merupakan pengembangan metode Robert dengan menggunakan filter HPF (High Pass Filter) yang diberi satu angka nol penyangga. Metode ini mengambil prinsip dari fungsi laplacian dan gaussian yang dikenal sebagai fungsi untuk membangkitkan HPF. Kelebihan dari metode Sobel ini adalah kemampuan untuk mengurangi noise sebelum melakukan perhitungan deteksi tepi. Pada Sobel Operator digunakan matriks neighbor berukuran 3x3 dengan titik yang sedang diperiksa sebagai titik tengah matriks. Sobel Operator ini diterapkan dalam dua buah matriks mask. Matriks mask adalah matrik yang berukuran $\mathrm{n}$ x $\mathrm{n}$ yang sama dengan matriks neighbor. Mask yang pertama (mask horisontal) digunakan untuk menghitung selisih antara titik pada sisi horizontal dan mask yang kedua (mask vertikal) digunakan untuk menghitung selisih antara titik pada sisi vertikal. Gambar hasil pengolahan dapat dilihat pada Tabel 3. 
Tabel 3. Proses Identifikasi Citra Janin

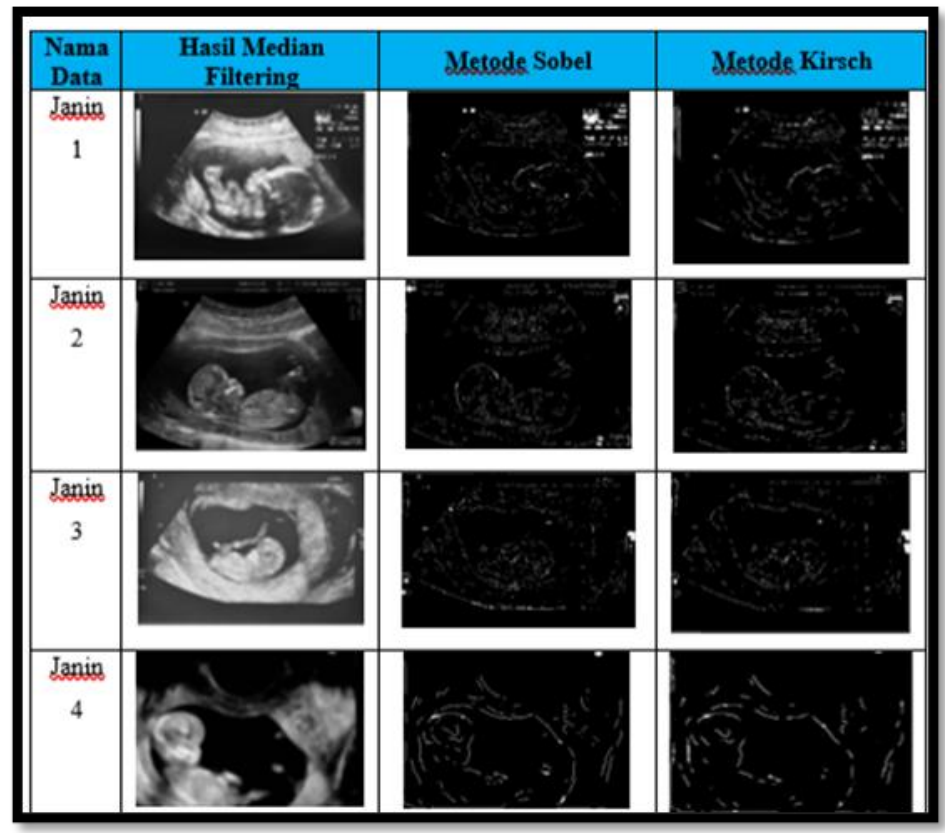

\subsection{Listing Program}

clc; clear; close all

$A=i m r e a d(' C: \backslash U s e r s \backslash E v r i t a$ Lusiana Utari \Pictures \janin3.jpg') ;

figure, imshow (A);

$\mathrm{B}=\operatorname{rgb} 2 \mathrm{gray} \quad(\mathrm{A})$;

figure, imshow(B);

$\mathrm{C}=$ medfilt2 $\left(\mathrm{B},\left[\begin{array}{ll}9 & 9\end{array}\right]\right)$;

figure, imshow(C);

$\mathrm{CCC}=$ fspecial ('average', [5 5]);

$\mathrm{CC}=$ imfilter $(\mathrm{C}, \mathrm{CCC})$;

figure, imshow (CC);

$\mathrm{D}=$ adapthisteq $(\mathrm{CC})$;

figure, imshow(D) ;

$\mathrm{DD}=i \mathrm{~m} 2 \mathrm{bw}$ (B) ;

figure, imshow (DD) ;

$0=\operatorname{edge}(\mathrm{D}$, 'sobel');

O = bwmorph (O, 'bridge', 'inf');

$0=\operatorname{imfill}\left(0\right.$, 'holes'); $^{\prime}$

figure, imshow (O) ; title ('SOBEL') ;

$\mathrm{R}=\operatorname{edge}(\mathrm{D}$, 'roberts');

$\mathrm{R}=$ bwmorph ( $\mathrm{R}$, 'bridge', 'inf');

$\mathrm{R}=\operatorname{imfill}(\mathrm{R}$, 'holes');

figure, imshow(R); title('ROBERTS'); 


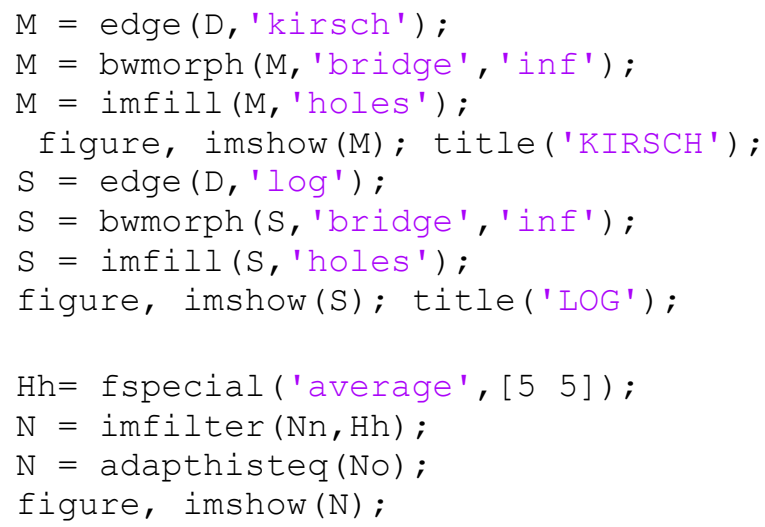

\subsection{Hasil Identifikasi Citra}

Penentuan tepian suatu objek dalam citra merupakan salah satu wilayah pengolahan citra digital yang paling awal dan paling banyak diteliti. Proses ini seringkali ditempatkan sebagai langkah pertama dalam aplikasi segmentasi citra, yang bertujuan untuk mengenali objek-objek yang terdapat dalam citra ataupun konteks citra secara keseluruhan.

Deteksi tepi berfungsi untuk mengidentifikasi garis batas (boundary) dari suatu objek yang terdapat pada citra. Tepian dapat dipandang sebagai lokasi piksel dimana terdapat nilai perbedaan intensitas citra secara ekstrem. Sebuah edge detector bekerja dengan cara mengidentifikasi dan menonjolkan lokasi-lokasi piksel yang memiliki karakteristik tersebut. Pada Citra janin yang berupa foto hasil USG janin, dilakukan filterisasi dengan menggunakan sistem medien filter. Dalam proses filterisasi ini noise berkurang cukup banyak sehingga data tampak lebih jelas, Selanjutnya dilakukan proses deteksi tepi dengan menggunakan metode sobel dan metode kirsch. Dengan menggunakan operator Sobel merupakan salah satu cara untuk menghindari gradien yang dihitung pada titik interpolasi dari pixel-pixel yang terlibat dengan cara menghaluskan citra digital. Proses penghalusan yang digunakan merupakan proses konvolusi dari jendela yang ditetapkan terhadap citra yang dideteksi dengan menggunakan jendela $3 \times 3$ dengan sistem kernel untuk perhitungan gradien, sehingga perkiraan gradien berada tepat ditengah jendela Sedangkan dengan menggunakan operator Kirsch dengan menggunakan jendela matriks $3 \times 3$ atau jendela ukuran $3 \times 3$ piksel, dengan k0 sampai k7. 
Tabel 4. Data Deteksi dan Histogram

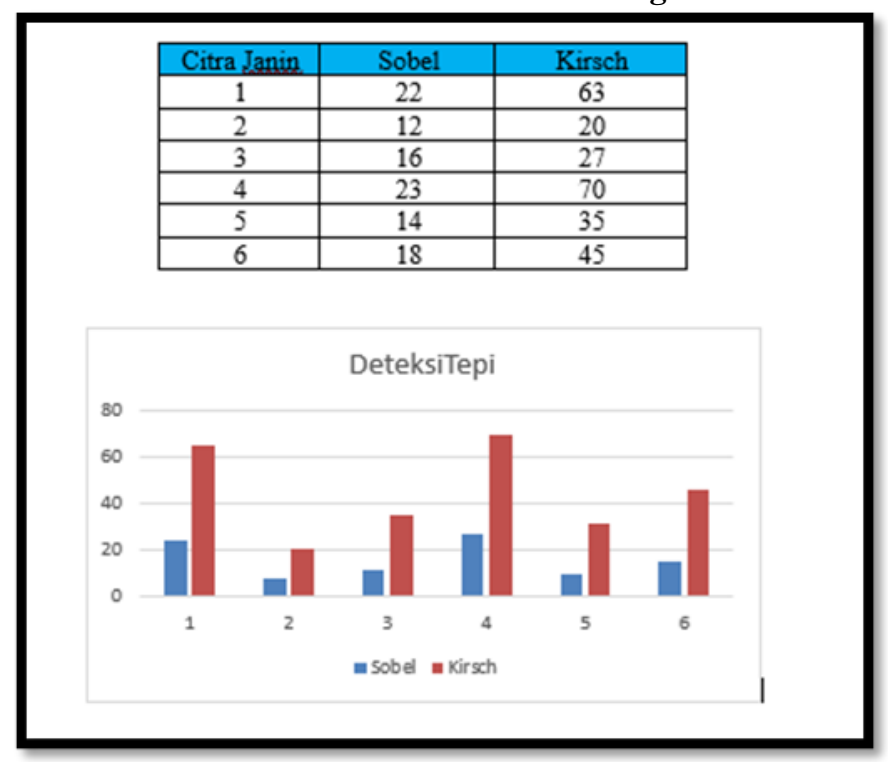

Dari hasil histogram tersebut dapat dilihat bahwa dalam sistem identifikasi deteksi antara metode Sobel dengan metode Kirsch terlihat metode Kirsch lebih baik dibandingkan dengan Sobel.

\section{KESIMPULAN}

1. Citra merupakan kamus Webster didefinisikan sebagai "Suatu representasi, kemiripan atau tiruan dari obyek atau sesuatu, suatu deskripsi grafik, atau sesuatu yang diperkenalkan untuk merepresentasikan sesuatu yang lain". Citra sesungguhnya merupakan gambaran isyarat dua dimensi. Dan untuk dapat diproses dengan menggunakan komputer, citra disajikan dalam bentuk digital. Citra digital memuat data numeris dalam dua dimensi (matriks) tentang keabuan (gray level) yang beragam nilainya pada tiap-tiap pixel (picture element).

2. Tepian citra adalah posisi di mana intesitas pixel dari citra berubah dari nilai rendah ke nilai tinggi atau sebaliknya. Deteksi tepi umumnya adalah langkah awal melakukan segmentasi citra. Tujuan deteksi tepi meningkatkan penampakan garis batas suatu daerah atau objek di dalam citra, mencirikan batas objek dan berguna untuk proses segmentasi dan identifikasi objek dan karena termasuk dalam komponen berfrekuensi tinggi, perlu filter high-pass.

3. Tahapan pra-pemrosesan meliputi pengolahan citra janin dengan menggunakan tapis melakukan pemfilteran oleh noise. Median filter adalah salah satu filtering non-linear yang mengurutkan nilai intensitas sekelompok pixel, kemudian mengganti nilai pixel yang diproses dengan nilai mediannya. Median filter telah digunakan secara luas untuk memperhalus dan mengembalikan bagian dari citra yang mengandung noise yang berbentuk bintik putih.

4. Sobel merupakan algoritma deteksi tepi yang hampir sama dengan prewitt, tetapi algoritma ini menggunakan sobel operator yang nilainya berbeda dengan prewitt operator. 
5. Kirsch adalah algoritma deteksi tepi yang banyak digunakan dalam berbagai penelitian karena dinilai sebagai algoritma deteksi tepi yang paling optimal. Langkah awal adalah mengimplementasikan tapis median untuk menghilangkan derau.

6. Pada penelitian ini telah dilakukan pengambilan data dengan 6 obyek citra janin yang berbeda. Dari hasil pengujian didapatkan hasil deteksi tepi yang berbeda-beda. Data deteksi yang paling baik dapat dilihat dengan metode Kirsch.

\section{DAFTAR PUSTAKA}

[1] Ahmad, U., (2005). Pengolahan Citra Digital dan Teknik Pemrogramannya, Graha Ilmu, Yogyakarta.

[2] Agustinus Nalwan. (1997) Pengolahan Gambar Secara Digital. Jakarta: PT Elex Media Komputindo, Hal: 209

[3] Chitade. Anil. Colour Based Image Segmentation Using K-Means Clustering. International Journal of Enggineering Science of Technology. USA.

[4] Divisi Kedokteran Fetomaternal Departemen OBGIN RSHS/FK Universitas Padjajaran. (2011). Ultrasonografi Obsetri dan Ginekologi. Jakarta.

[5] EL. Utari. (2015), Analisa Deteksi Tepi Janin Dengan Menggunakan Metode Prewitt Dan Canny, Simposim RAPI ke 14, Universitas Muhamadiyah Surakarta

[6] Gonzalez, R. C., Woods, R.E., (2002). Digital Image Processing second edition, New Jersey: Prentice-Hall, Inc.

[7] Lusiana, Veronica. (2013). Analisa Deteksi Tepi untuk mengidentifikasi Pola Daun, Jurnal Teknologi Informasi Vol. 18 No 2. Universitas Diponegoro, Semarang.

[8] Munir, R. (2004). Pengolahan Citra Digital dengan pendekatan Algoritmik, Informatika Bandung.

[9] Endjun, Januadi. (2007)," Obstetri dan Ginekologi”, Fakultas Kedokteran Universitas Indonesia. Jakarta.

[10] Nur Cholis, M (2014). Aplikasi Deteksi Tepi Sobel Untuk Identifikasi Tepi Citra Medis, MATHunesa Volume 3 Nomor 2. Universitas Negeri Surabaya.

[11]Prasetyo, E. (2011). Pengolahan Citra Digital dan Aplikasinya menggunakan Matlab, Penerbit Andi Yogyakarta.

[12] Purnomo, Hari Mauridhi. (2010) Konsep Pengolahan Citra Digital dan Ekstraksi Fitur, Graha Ilmu Yogyakarta.

[13] Syari, Milea dkk. (2015). Peran Asupan Zat Gizi Makronutrien Ibu Hamil Terhadap Berat Badan Lahir Bayi, Jurnal Kesehatan Andalas, Universitas Andalas, Padang. 